$\mathrm{DE}$

M E D I C I N A

T R O P I C A L

$\mathrm{DE}$

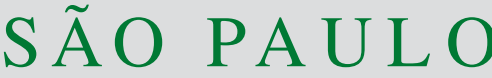

JOURNAL OF THE SÃO PAULO INSTITUTE OF TROPICAL MEDICINE

'Universidade Federal de Pelotas, Instituto de Biologia, Programa de Pós-Graduação em Parasitologia, Pelotas, Rio Grande do Sul, Brazil

${ }^{2}$ Centro Estadual de Vigilância em Saúde, Porto Alegre, Rio Grande do Sul, Brazil

Correspondence to: Tanise Freitas Bianchi Universidade Federal de Pelotas, Instituto de Biologia, Programa de Pós-Graduação em Parasitologia, Campus Universitário Capão do Leão, S/N, CEP 96010-900, Pelotas, Rio Grande do Sul, Brazil Tel: +55 53 2341-7686 +5553999667811

E-mail: tanisebianchi@ hotmail.com

Received: 5 March 2021

Accepted: 11 May 2021

\section{Current situation of Chagas disease vectors (Hemiptera, Reduviidae) in Southern Rio Grande do Sul State, Brazil}

\author{
Tanise Freitas Bianchi ${ }^{\circledR 1}$, Sabrina Jeske ${ }^{(1)}$, Ana Paula da Paz Grala ${ }^{\circledR}$, Italo \\ Ferreira de Leon ${ }^{(1)}$, Cleonara Bedin ${ }^{\circledR}$, Fernanda de Mello ${ }^{\circledR}$, Guilherme \\ Carlos Castilhos da Silva ${ }^{\circledR}$, Marcos Marreiro Villela ${ }^{\left({ }^{\circ}\right.}$
}

\section{ABSTRACT}

Chagas disease (CD) has been considered endemic in the South of Rio Grande do Sul (RS) State, Brazil. This study aimed at evaluating the occurrence of Trypanosoma cruzi vectors based on the main species captured in Southern Rio Grande do Sul State from 2008 to 2019. The study area comprised counties that belong to the $3^{\text {rd }}$ Regional Health Coordination (RHC) and to the $7^{\text {th }}$ RHC, whose headquarters are in Pelotas and Bage, respectively. The study was based on secondary data provided by the partnership between the Federal University of Pelotas, Rio Grande do Sul State (UFPel-RS) and the State Health Surveillance Center in RS (SCHS-RS). One thousand and four hundred triatomines were captured in the area supervised by the $3^{\text {rd }}$ RHC, mainly in Cangucu (37.7\%), Piratini $(22.4 \%)$ and Pinheiro Machado (15.1\%), while, in the area supervised by the $7^{\text {th }}$ RHC, the largest number of triatomines was captured in Lavras do Sul (64.15\%). In both areas, Triatoma rubrovaria (90.6\%) and Panstrongylus tupynambai (7.4\%) were the most common species. Most were captured inside households but $T$. cruzi-positive insects were not found in the period under study. The results of this study show that, in Southern Rio Grande do Sul State, there is still a high rate of triatomine household invasion and dispersal, mainly by T. rubrovaria. Thus, the entomological surveillance should be maintained with the participation of the population and further studies should be deepened in the area.

KEYWORDS: Trypanosoma cruzi. Triatoma rubrovaria. Panstrongylus tupynambai. Vector control. Rio Grande do Sul. Chagas disease.

\section{INTRODUCTION}

Chagas disease (CD), which is caused by the protozoan Trypanosoma cruzi, has been considered one of the world's most neglected tropical disease by the World Health Organization (WHO). It is a result of the vectors geographical dispersal since the disease affects mainly low-income countries in Latin America, where there are high morbi-mortality rates, considerable socioeconomic impact, limited resources and low political priority to combat the disease ${ }^{1,2}$.

T. cruzi is mostly transmitted by vectors (hemipterans that belong to the subfamily Triatominae) whose infectant forms are eliminated in triatomine feces and urine, either throughout or right after the blood meal. Protozoans penetrate the human skin through puncture holes resulting from insect stings or their scarification caused by scratching, and through mucous and conjunctiva membranes, when individuals rub their noses, mouths or eyes with infected hands. The main means of infection with $T$. cruzi is by vector transmission, equivalent to $80 \%$ of Chagas disease cases ${ }^{3}$, however, other 
modes of infection include blood transfusion; congenital transmission; organ transplantation; laboratory accidents and, mainly, oral transmission, through contaminated foods such as sugar cane juice and acai, with the majority of reported cases found in the Amazon region. The Ministry of Health of Brazil counted 112 outbreaks in the national territory between the years 2005 to 2013, most of them occurred in the Para, $75.9 \%$ (85 outbreaks) and Amapa, $12.5 \%$ states $^{1,2,4}$.

The main environment in which $T$. cruzi transmission takes place is poorly constructed and preserved houses that characterize of low social and economic conditions. Vector domiciliation is related to the opportunity for triatomines to find shelters and burrows, food availability and different degrees of anthropophilia of each species ${ }^{5}$.

Camargo et al. ${ }^{6}$ carried out a serological survey showing that Rio Grande do Sul (RS) and Minas Gerais (MG) were the Brazilian States that had the highest human seroprevalence index of $T$. cruzi $(8.8 \%)$.

Chagas disease has been considered endemic in Southern $\mathrm{RS}^{7}$. It is noteworthy that these municipalities, geographically remarkably close, had high rates of home infestation by $T$. infestans in previous decades ${ }^{8}$. Therefore, prevalence in patients from this area is still considered one of the highest in the state and sero-reactivity to T. cruzi was found in individuals under the age of $30^{9,10}$. Even though it is now less common than in the past, implying that vectors may still be one of the modes of transmission in this area.

Although T. infestans has been eliminated in RS State, there are other triatomine species that persist in rural households ${ }^{11}$. Therefore, this study aimed at evaluating the occurrence of $\mathrm{CD}$ vectors based on the main species captured in Southern RS, from 2008 to 2019.

\section{MATERIALS AND METHODS}

\section{Characterization and period of study}

This is a retrospective descriptive study of CD vectors based on secondary data provided by the Chagas Disease Control Program (CDCP), carried out by the partnership between the Universidade Federal de Pelotas (UFPel), located in Pelotas, RS, and the State Health Surveillance Center in RS that belongs to the State Health Department (SCHS-SHD-RS).

The investigation comprised the latest results provided by the SCHS, i.e., data collected in the last 12 years, from 2008 to 2019. Both data and entomological information from 2008 to 2016 were found in the CDCP-DATASUS system, while the ones between 2017 and 2019 were collected from the Formulary for Entomological Surveillance of CD (FORMSUS-DATASUS).

\section{Choice of the area and its description (study area)}

Considering the high prevalence of $\mathrm{CD}$ and the number of vectors in Southern RS, shown by previously mentioned evaluations, - the area chosen for this study comprised counties that belong to the $3^{\text {rd }}$ RHC and the $7^{\text {th }}$ RHC in RS, Brazil.

The $3^{\text {rd }}$ RHC, whose headquarters are in Pelotas, RS, comprises 22 counties (Amaral Ferrador, Arroio do Padre, Arroio Grande, Capao do Leao, Cangucu, Cerrito, Chui, Cristal, Herval, Jaguarao, Morro Redondo, Pedras Altas, Pedro Osorio, Pelotas, Pinheiro Machado, Piratini, Rio Grande, Santa Vitoria do Palmar, Santana da Boa Vista, Sao Jose do Norte, Sao Lourenco do Sul and Turucu), 845,135 inhabitants $^{12}$ and has a degree of urbanization of $83.64 \%^{13}$ (Figure 1). The $7^{\text {th }}$ RHC has its headquarters in Bage, RS, and comprises 6 counties (Acegua, Bage, Candiota, Dom Pedrito, Hulha Negra and Lavras do Sul), 182,579 inhabitants $^{12}$ and has a degree of urbanization of $78.49 \%{ }^{13}$ (Figure 2).

Regarding environmental aspects, this region is part of the Pampa Biome, characterized by field vegetation and lowland relief, formed by dense, tree and shrub vegetation, on the slopes and along water courses, with the occurrence of wetlands and also of natural pastures ${ }^{14}$.

\section{Description of entomological surveillance in the area}

In counties that belong to both, $3^{\text {rd }}$ and $7^{\text {th }}$ RHCs, as well as in other Brazilian regions, passive surveillance is carried out by the population when individuals notify the occurrence of vectors to the Triatomine Information Center (TIC). TICs, which have been implemented in tactical spots, such as schools and health centers, are the main strategies of vector control. City health agents go to the TICs monthly and, if there is any confirmed notification, i.e., the captured insect is actually a triatomine, a visit to the household is scheduled within a month (counting from the day the insect was collected). Since the process of registering notifications/ confirmations is mandatory, they are available in the SCHS.

According to the rules proposed by the Ministry of Health, the search is carried out in peridomicile and in intradomicile. It includes the analysis of people's households and the search for shelter and animals that may serve as food sources for triatomines ${ }^{15}$.

\section{Statistical analysis of data}

The following variables were characterized by this study: vector species found in the area, level of triatome infestation per county; index of $T$. cruzi infection of triatomines captured per county (number of captured kissing 


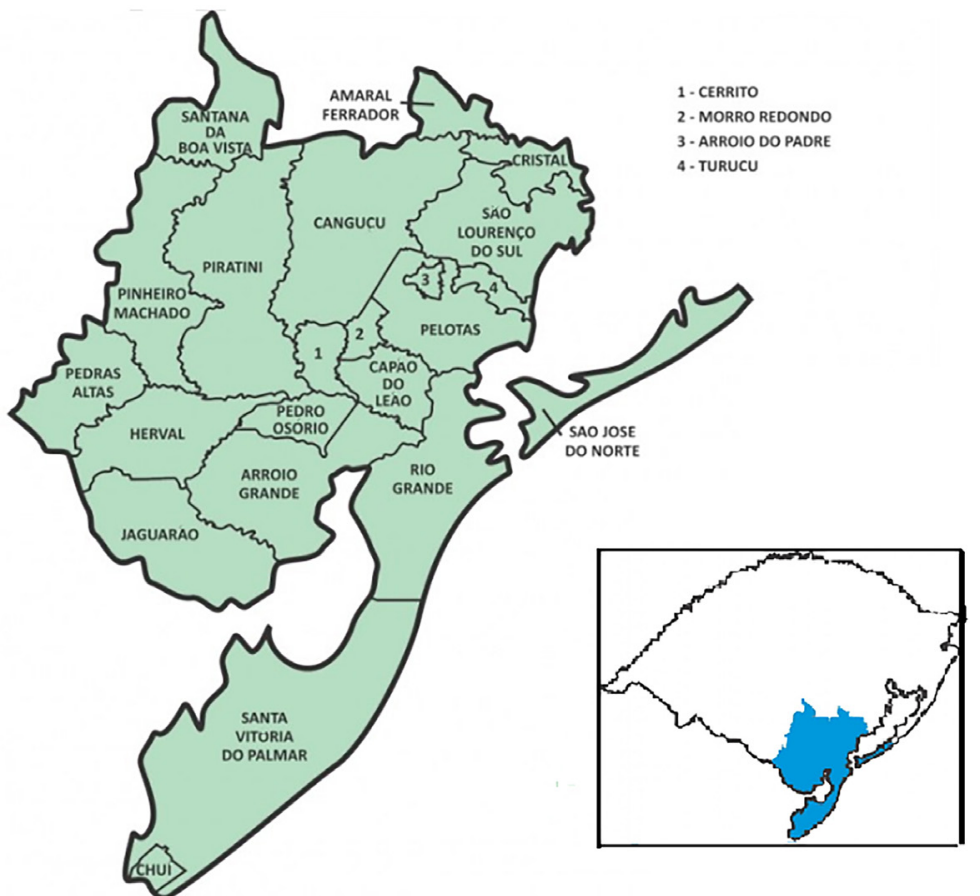

Figure 1 - Map of cities that belong to the $3^{\text {rd }} \mathrm{RHC}$; headquarters in Pelotas, RS State, Brazil.

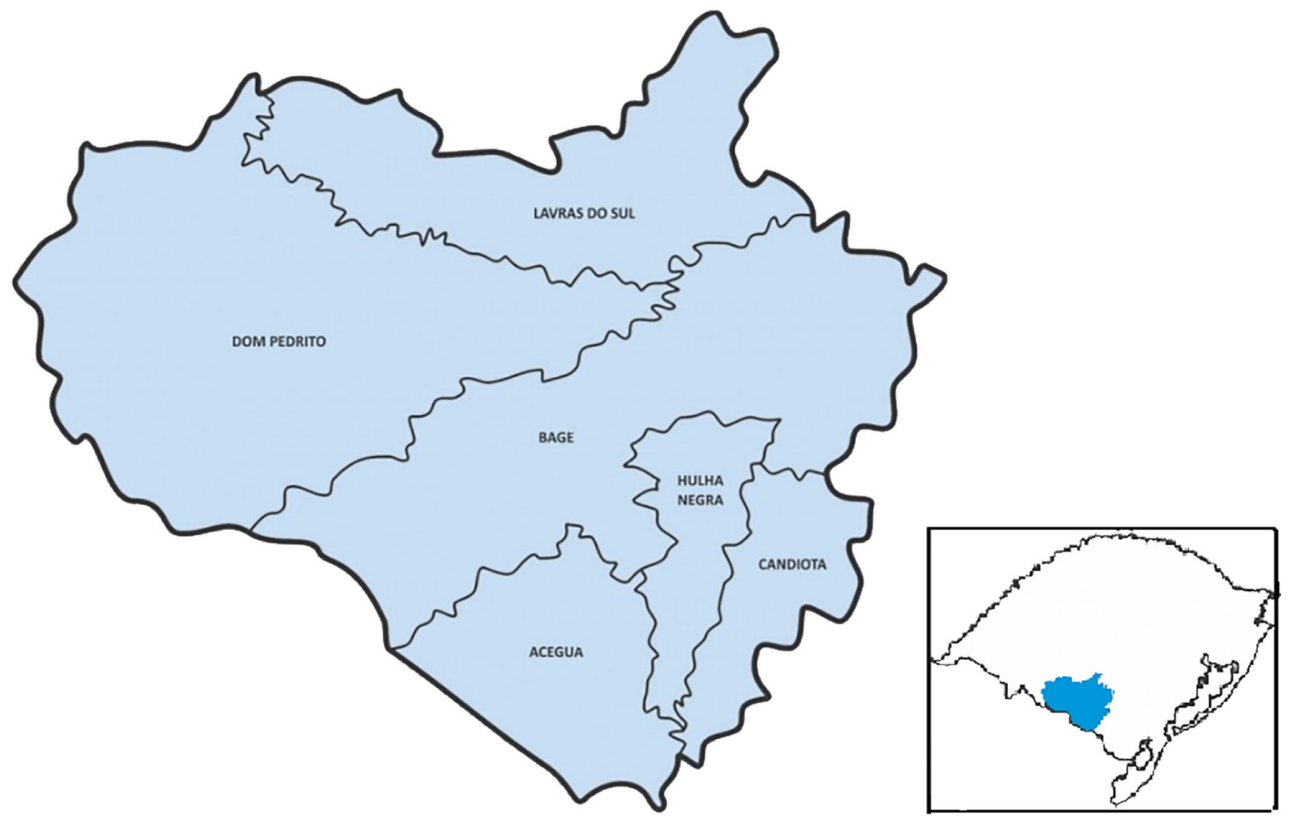

Figure 2 - Map of cities that belong to the $7^{\text {th }} \mathrm{RHC}$; headquarters in Bage, RS State, Brazil.

bugs/number of examined kissing bugs/percentage of T. cruzi-positive bugs); infestation frequency of households and the peri-domicile; and geographical dispersal of species captured in both RHC.

Data tabulation was carried out by the Microsoft Excel ${ }^{\circledR}$ program and a database was build up. Values were expressed as frequencies (observed value $\mathrm{n}$ ) and percentages. Variables were statistically compared by the Chi-Square Test $\left(\chi^{2}\right)$; values of $p \leq 0.05$ were considered significant. The period under evaluation (2008-2019) was divided into six biennia. The statistical analysis was conducted by the MINITAB $^{\circledR}$ program (version 18, Minitab LLC, Pennsylvania, EUA). The Odds Ratio Test was applied to statistically significant values.

\section{RESULTS}

Reports showed that 1,400 triatomines were captured in the counties that belong to the $3^{\text {rd }} \mathrm{RHC}$ (Pelotas) from 2008 
to 2019 (Table 1). A decrease in the number of captures was observed in this period. The biennium with the largest number of captures was 2008-2009, when 579 insects were registered, corresponding to $41.7 \%$ of the total. The comparison between the first three biennia and the last three ones showed a statistically significant difference $(\mathrm{p}=0.04$; $\mathrm{OR}=3.26, \mathrm{IC}_{95}=1.04-10.16$ ).

Regarding the counties that comprise the $7^{\text {th }} \mathrm{RHC}$ (Bage) (Table 2), 159 triatomines were captured between 2008 and 2019. A decrease in the number of captured insects was also observed in the period, and 2008-2009 was again the biennium with the largest number of captures (63), corresponding to $39.60 \%$ of the total. However, the comparison between the first three biennia and the last three ones did not show any statistically significant difference $(\mathrm{p}=0.72)$.

Cangucu (37.71\%), Piratini (22.43\%) and Pinheiro Machado (15.07\%) were the counties in the $3^{\text {rd }} \mathrm{RHC}$ where more triatomines were captured, while in the $7^{\text {th }}$ RHC, Lavras do Sul was the county where more triatomines were captured $(64.15 \%)$ (Table 4).

In both RHCs, the largest number of specimens belonged to the species Triatoma rubrovaria (90.63\%), followed by Panstrongylus tupynambai (7.37\%).

No T. cruzi-positive insects were detected in the study period and most triatomines were captured intradomicile (Tables 3 and 4).
Concerning the species dispersal, in the $3^{\text {rd }}$ RHC, T. rubrovaria was found in $16(72.20 \%)$ out of 22 counties, while $P$. tupynambai was found in seven counties and T. carcavalloi was only found in Cangucu (1 capture) (Table 3). In the $7^{\text {th }}$ RHC, $T$. rubrovaria was identified in Bage, Candiota, Dom Pedrito, Hulha Negra and Lavras (83.30\% of counties), P. tupynambai was detected in Bage, Dom Pedrito and Lavras and P. megistus was only found in Acegua (Table 3).

\section{DISCUSSION}

Chagas disease has been investigated in RS State since the beginning of the $20^{\text {th }}$ century. Arthur Neiva, who registered the first triatomines between 1911 and 1914, identified Triatoma infestans and T. rubrovaria and this was the first record of T. rubrovaria in Brazil ${ }^{16,17}$.

It should be highlighted that $T$. rubrovaria requires attention, since Silva and Silva ${ }^{18}$ found that it is a competent agent of $T$. cruzi transmission due to its bionomic characteristics. Besides, its importance may be compared to the one of other species, such as T. infestans ${ }^{19}$.

The study carried out by Almeida et al. ${ }^{20}$ showed the increasing frequency of T. rubrovaria in rural households in Southeastern RS State and stated these authors claimed that this species may be invading areas that had been previously occupied by $T$. infestans, the main domestic $\mathrm{CD}$ vector

Table 1 - Number and ratio of triatomines captured in the area that belongs to the $3^{\text {rd }} \mathrm{RHC}$ in Pelotas, RS State, Brazil, in different biennia.

\begin{tabular}{cccc}
\hline Time corse (biennium) & Number of triatomines & \% Total & Average per year \\
\hline $2008-2009^{\mathrm{a}}$ & 579 & 41.36 & 289.50 \\
$2010-2011^{\mathrm{a}}$ & 246 & 17.57 & 123.00 \\
$2012-2013^{\mathrm{a}}$ & 246 & 10.36 & 123.00 \\
$2014-2015^{\mathrm{b}}$ & 145 & 10.36 & 72.50 \\
$2016-2017^{\mathrm{b}}$ & 107 & 7.64 & 53.50 \\
$2018-2019^{\mathrm{b}}$ & 77 & 5.50 & 38.50 \\
\hline Total & 1400 & 100 & 116.70 \\
\hline $\mathrm{a}^{\mathrm{b} *} \mathrm{p}=0,04$ & & &
\end{tabular}

Table 2 - Number and ratio of triatomines captured in the area that belongs to the $7^{\text {th }} \mathrm{RHC}$ in Bage, RS State, Brazil, in different biennia.

\begin{tabular}{cccc}
\hline Time corse (biennium) & Number of triatomines & $\% /$ Total & Average per year \\
\hline $2008-2009^{\mathrm{a}}$ & 63 & 39.60 & 31.50 \\
$2010-2011^{\mathrm{a}}$ & 09 & 5.70 & 4.50 \\
$2012-2013^{\mathrm{a}}$ & 16 & 10.10 & 8.00 \\
$2014-2015^{\mathrm{b}}$ & 31 & 19.50 & 15.50 \\
$2016-2017^{\mathrm{b}}$ & 16 & 10.10 & 8.00 \\
$2018-2019^{\mathrm{b}}$ & 24 & 15.10 & 12.00 \\
\hline Total & 159 & 100 & 13.25 \\
\hline
\end{tabular}

$\overline{\mathrm{a} \times \mathrm{b} * \mathrm{p}=0,72}$ 
Table 3 - Triatomine species captured between 2008 and 2019 in the counties that belong to the $3^{\text {rd }}$ RHC in Pelotas, RS State, Brazil, places of capture and analysis of Trypanosoma cruzi.

\begin{tabular}{|c|c|c|c|c|c|c|c|}
\hline Counties & Species & Intra & Peri & Not assigned & Analyzes & Positive & $\begin{array}{l}\text { Total } \\
\mathrm{n}(\%)\end{array}$ \\
\hline \multirow{5}{*}{ Cangucu } & P. megistus & 01 & - & - & - & - & \multirow{5}{*}{$\begin{array}{c}528 \\
(37.71 \%)\end{array}$} \\
\hline & T. rubrovaria & 494 & 12 & - & 74 & 0 & \\
\hline & P. tupynambai & 02 & 01 & 13 & - & - & \\
\hline & T.carcavalloi & - & - & 01 & - & - & \\
\hline & T. circummaculata & - & - & 04 & - & - & \\
\hline Cerrito & T. rubrovaria & 51 & 0 & - & 0 & - & $\begin{array}{c}51 \\
(3.65 \%)\end{array}$ \\
\hline \multirow{2}{*}{ Jaguarao } & T. rubrovaria & 22 & 16 & - & 15 & \multirow[b]{2}{*}{-} & 43 \\
\hline & T. circummaculata & - & - & 05 & - & & $(3.07 \%)$ \\
\hline \multirow{3}{*}{ Pedras Altas } & T.rubrovaria & 36 & 04 & - & \multirow{3}{*}{$\begin{array}{c}02 \\
-\end{array}$} & \multirow{3}{*}{$\begin{array}{l}0 \\
-\end{array}$} & \multirow{3}{*}{$\begin{array}{c}52 \\
(3.71 \%)\end{array}$} \\
\hline & P. tupynambai & - & - & 09 & & & \\
\hline & T. circummaculata & - & - & 03 & & & \\
\hline \multirow{3}{*}{$\begin{array}{l}\text { Pinheiro } \\
\text { Machado }\end{array}$} & T.rubrovaria & 155 & 16 & - & 43 & 0 & \multirow{3}{*}{$\begin{array}{c}211 \\
(15.07 \%)\end{array}$} \\
\hline & T. tupynambai & 02 & 01 & 34 & 02 & - & \\
\hline & T. circummaculata & - & - & 03 & - & - & \\
\hline \multirow{3}{*}{ Piratini } & T. rubrovaria & 277 & 10 & - & 54 & 0 & \multirow{3}{*}{$\begin{array}{c}314 \\
(22.43 \%)\end{array}$} \\
\hline & T. tupynambai & 02 & - & 23 & - & - & \\
\hline & T. circummaculata & - & - & 02 & - & - & \\
\hline \multirow{3}{*}{$\begin{array}{c}\text { Santana da Boa } \\
\text { Vista }\end{array}$} & T. rubrovaria & 85 & 01 & - & 14 & 0 & \multirow{3}{*}{$\begin{array}{c}98 \\
(7.00 \%)\end{array}$} \\
\hline & P.tupynambai & - & - & 11 & - & - & \\
\hline & P. megistus & 01 & - & - & - & - & \\
\hline \multirow{4}{*}{ Others } & P. megistus & & & - & & & \multirow{4}{*}{$\begin{array}{c}103 \\
(7.36 \%)\end{array}$} \\
\hline & T. rubrovaria & $\begin{array}{l}06 \\
85\end{array}$ & $\overline{06}$ & - & - & - & \\
\hline & P. tupynambai & 85 & 06 & 05 & - & - & \\
\hline & T. circummaculata & - & - & 01 & - & - & \\
\hline Total & & 1219 & 67 & 114 & 204 & 0 & $\begin{array}{c}1,400 \\
(100 \%)\end{array}$ \\
\hline
\end{tabular}

Table 4 - Triatomine species captured between 2008 and 2019 in the counties that belong to the $7^{\text {th }}$ RHC in Bage. RS. Brazil. Places of capture and analysis of Trypanosoma cruzi.

\begin{tabular}{|c|c|c|c|c|c|c|c|}
\hline Counties & Species & Intra & Peri & Not assigned & Analyzes & Positive & $\begin{array}{l}\text { Total } \\
\text { n (\%) }\end{array}$ \\
\hline Acegua & P. megistus & 01 & - & - & 01 & 0 & $\begin{array}{c}01 \\
(0.63 \%)\end{array}$ \\
\hline Bage & $\begin{array}{l}\text { T. rubrovaria } \\
\text { P. tupynambai }\end{array}$ & $\begin{array}{l}14 \\
02\end{array}$ & $\begin{array}{c}04 \\
-\end{array}$ & - & $\begin{array}{l}0 \\
0\end{array}$ & - & $\begin{array}{c}23 \\
(14.46 \%) \\
\end{array}$ \\
\hline Candiota & T. rubrovaria & 06 & - & - & 0 & - & $\begin{array}{c}06 \\
(3.78 \%) \\
\end{array}$ \\
\hline D.Pedrito & $\begin{array}{c}\text { T. rubrovaria } \\
\text { T. circummaculata } \\
\text { P. tupynambai }\end{array}$ & $\begin{array}{l}19 \\
01\end{array}$ & 03 & $\begin{array}{l}- \\
01 \\
02 \\
\end{array}$ & $\begin{array}{l}0 \\
0\end{array}$ & - & $\begin{array}{c}26 \\
(16.35 \%)\end{array}$ \\
\hline Hulha Negra & T. rubrovaria & 01 & - & - & 0 & - & $\begin{array}{c}01 \\
(0.63 \%) \\
\end{array}$ \\
\hline Lavras do Sul & $\begin{array}{c}\text { T. rubrovaria } \\
\text { P. tupynambai } \\
\text { T. circummaculata }\end{array}$ & $\begin{array}{l}75 \\
03\end{array}$ & 15 & $\begin{array}{l}06 \\
02 \\
01 \\
\end{array}$ & 06 & - & $\begin{array}{c}102 \\
(64.15 \%)\end{array}$ \\
\hline Total & & 122 & 22 & 15 & 07 & 0 & $\begin{array}{c}159 \\
(100 \%)\end{array}$ \\
\hline
\end{tabular}

which was eliminated in the State by chemical control ${ }^{11}$, corroborating the findings of this study.

Triatomine invasion has decreased lately. In both, $3^{\text {rd }}$ $\mathrm{RHC}$ and $7^{\text {th }} \mathrm{RHC}$, the largest number of captures took place in the first biennium under investigation (2008-2009), when about $40 \%$ of the total number of bugs were captured. Reduction in the number of captures would be a result of several processes and induction agents, such as the use of residual pesticides, environmental management and improvement of rural households, besides educational 
projects carried out in the counties ${ }^{7,21}$. According to Priotto et al..$^{22}$, the decrease in the number of insects in the households is apparently not associated with the population's knowledge of CD vectors, since some studies have shown how insufficient is the knowledge of people about vectors in endemic areas, preventing the adoption of actions that prevent different endemics from advancing ${ }^{23,24}$. This supposition is corroborated by the fact that there has been a decrease in people's knowledge on $\mathrm{CD}$ vectors and of the disease notification lately, as shown by a study conducted by Bianchi et al. ${ }^{25}$, who observed that older adults are more aware of the topic than youngsters.

Dutra et $a l .{ }^{26}$ carried out a study in patients with heart diseases who used the public assistance service provided by the Cardiology Outpatient Clinic that belongs to the UFPel, in Pelotas, RS State. These patients, who came from Cangucu, Herval, Pinheiro Machado and Piratini, counties in which $\mathrm{CD}$ was considered endemic in the 1980's. In these localities, vectors were properly identified, a fact that partially corroborates the findings of this study, since these counties are among those that notified large numbers of triatomines in the $3^{\text {rd }}$ RHC. Such factor may make the population in Cangucu more experienced in the identification of kissing bugs. As a result, this investigation shows that many vectors were captured in the county. Another fact that collaborates this finding is the high index of infection caused by T. cruzi (10\%) found by Rosenthal et al..$^{27}$ in patients from Cangucu, the county that has the highest populational prevalence of antibodies anti - T. cruzi.

Therefore, Cangucu, Piratini and Pinheiro Machado exhibited the largest number of captured triatomines, a fact that agrees with findings published by Priotto et al. ${ }^{22}$, who showed that Cangucu, Piratini, Santana da Boa Vista and Pinheiro Machado had the highest indexes of infestation by triatomines, that were also T. rubrovaria $(93.9 \%)$ and P. tupynambai (5.1\%). It should be emphasized that these counties have a historical importance regarding $\mathrm{CD}$, since they are geographically close to each other and, in the past, used to have low-quality households in their rural areas. As a result, they had high indexes of household infestation with T. infestans ${ }^{8}$. Besides, Cangucu is one of five counties in RS State with the largest numbers of TICs (30), a fact that contributes to increase vector notifications. In other words, the population is more sensitive towards vector identification because of historical issues and there are more TICs distributed around the county favoring the notifications about vectors detections ${ }^{17}$.

No T. cruzi-positive insects were detected in the period, mainly because of the material bad preservation, since most insects were dry when analyses were carried out, corroborating data by Priotto et al..$^{22}$ in the same and nearby region. Ribeiro et al. ${ }^{28}$ isolated $T$. cruzi strains from triatomines that belong to the species $T$. rubrovaria, captured in households, peridomicile and in the wild in RS State. Considering all examined specimens, the index of natural infection caused by the protozoan was 3.65\%, which was similar to the percentage found by Martins et $a l .^{29}$ in six areas in Quarai, RS State, in a study carried out in the municipality of Quarai, showing that $4.2 \%$ of $T$. rubrovaria triatomines were infected. It should be mentioned that, in Quarai, P. tupynambai was also found co-inhabiting stone fissures with a lizard that belongs to the species Tupinambis merianae (giant tegu). This lizard has a very varied diet that includes triatomines and it can acquire natural infection by $T$. cruzi, as has already been described.

Regarding the infections, it is important to consider that captured triatomines must be delivered to the laboratory as soon as possible so that their intestinal contents can be evaluated for positivity to $T$. $c r u z i^{30}$. In addition, the implementation of molecular techniques, such as the PCR (Polymerase Chain Reaction), is very important for the protozoan diagnosis, since such techniques increase sensitivity of $T$. cruzi detection, mainly in the cases of dead and dry insects. However, they have high cost in comparison with microscopic evaluations, a limiting factor in the Brazilian public health system ${ }^{31,32}$.

The small number of triatomines found in the peridomicile, in both RHCs in the period under investigation should be mentioned. However, if the program is working well, promoting the population's and health agents' cooperation, this finding should not be considered normal, since the largest spots and frequency of insects usually occur in the peridomicile because triatomines often find low-quality facilities in this area, such as chicken and pig pens, barns and rupestrian walls, which are typical in RS State $^{20,21,33}$. They have cracks that enable triatomines to hide and represent a rich source of nutrients, mainly in chicken pens and spots where rodents and wild birds build their nests.

After T. infestans was controlled in RS State, the most captured triatomine species became T. rubrovaria ${ }^{34}$, whose food sources are several invertebrate and vertebrate hosts, such as humans. These vectors are mainly found amid rocks and stones ${ }^{35}$. Silveira and Rezende ${ }^{36}$ showed that T. rubrovaria can colonize human households and other studies highlighted that there has been an increment in the number of T. rubrovaria in Southern Brazil in the last 20 years $^{20}$, a result that was also found by this investigation, since this species represented $90.6 \%$ of captures in Southern Brazil from 2008 to 2019. 


\section{CONCLUSION}

Despite some limitations of this study, such as the fact that it is based on secondary data, it shows unequivocal data that confirm that, in Southern Brazil, even with a decrease in the capture of $T$. cruzi vectors in the period under investigation, there is still significant household invasion and dispersal of triatomines, mainly $T$. rubrovaria and $P$. tupynambai. The population's awareness on $\mathrm{CD}$ and its vectors must improve and emphasis has to be given to the search for suspicious insects in the peridomicile, especially in chicken pens, barns and dumpsites. Besides, health agents of the program could conduct an active survey in Southern RS State, mainly in the peridomicile, and deliver the vectors to the CPHL-RS immediately after for $T$. cruzi detection, aiming at corroborating data shown in this study. Thus, even though the program was successful in the biennia under investigation, when there was a significant decrease in the numbers of captured vectors, activities of entomological surveillance are still essential and the community's active participation should be stimulated so as to reach an effective and sustainable control of CD vectors in Southern RS State.

\section{CONFLICT OF INTERESTS}

The authors declare no conflict of interests.

\section{REFERENCES}

1. Rassi Jr A, Rassi A, Marin-Neto JA. Chagas disease. Lancet. 2010;375:1388-402.

2. World Health Organization. Chagas disease in Latin America: an epidemiological update based on 2010 estimates. Wkly Epidemiol Rec. 2015;90:33-43.

3. Aras R, Gomes I, Veiga M, Melo A. Transmissão vetorial da doença de Chagas em Mulungu do Morro, Nordeste do Brasil. Rev Soc Bras Med Trop. 2003;36:359-63.

4. Brasil. Ministério da Saúde. Secretaria de Vigilância em Saúde. Doença de Chagas aguda no Brasil: série histórica de 2000 a 2013. Bol Epidemiol. 2015;46: 1-9.

5. Silveira AC. Situação do controle da transmissão vetorial da doença de Chagas nas Américas. Current situation with Chagas disease vector control in the Americas. Cad Saude Publica. 2000;16 Suppl 2:35-42.

6. Camargo ME, Silva GR, Castilho EA, Silveira AC. Inquérito sorológico de prevalência da infecção chagásica no Brasil, 1975/1980. Rev Inst Med Trop Sao Paulo. 1984;26:192-204.

7. Bedin C, Mello F, Wilhelms TS, Torres MA, Estima C, Ferreira CF, et al. Vigilância ambiental: doença de Chagas no Rio Grande do Sul. Bol Epidemiol. 2009;11:1-8.
8. Baruffa G, Alcantara Filho A. Inquérito sorológico e entomológico da infecção pelo T. cruzi na região Sul do Rio Grande do Sul, Brasil. Ann Soc Belg Med Trop. 1985;65 Suppl 1:171-9.

9. Rosenthal LA, Petrarca CR, Mesenburg MA, Villela MM. Trypanosoma cruzi seroprevalence and associated risk factors in cancer patients from Southern Brazil. Rev Soc Bras Med Trop. 2016;49:768-71.

10. Stauffert D, Silveira MF, Mesenburg MA, Manta AB, Dutra AS, Bicca GL, et al. Prevalence of Trypanosoma cruzi/HIV coinfection in southern Brazil. Braz J Infect Dis. 2017;21:1804.

11. Bedin C, Wilhelms T, Villela MM, Silva GC, Riffel AP, Sackis P, et al. Residual foci of Triatoma infestans infestation: surveillance and control in Rio Grande do Sul, Brazil, 2001-2018. Rev Soc Bras Med Trop. 2021;54:e0530-2020.

12. Instituto Brasileiro de Geografia e Estatística. Censo 2010. [cited 2021 May 11]. Available from: http://www.censo2010.ibge. gov.br

13. Rio Grande do Sul. Secretaria de Planejamento, Governança e Gestão. Atlas socioeconômico Rio Grande do Sul: demografia: taxa de urbanização. [cited 2021 May 11]. Available from: https://atlassocioeconomico.rs.gov.br/grau-de-urbanizacao

14. Empresa Brasileira de Pesquisa Agropecuária. Pampa. [cited 2021 May 11]. Available from: https://www.embrapa.br/contandociencia/bioma-pampa

15. Silva RA, Rodrigues VL, Carvalho ME, Pauliquévis Jr C. Programa de controle da doença de Chagas no Estado de São Paulo: persistência de alta infestação por triatomíneos em localidades na década de 1990. Cad Saude Publica. 2003;19:965-71.

16. Oliveira G. Tripanosomiasis cruzi (doença de Carlos Chagas) no Rio Grande do Sul, Brasil. Mem Inst Oswaldo Cruz. 1942;37:443-537.

17. Rio Grande do Sul. Secretaria de Estado da Saúde. Centro Estadual de Vigilância em Saúde. Divisão de Vigilância Ambiental em Saúde. Informe de situação no estado do Rio Grande do Sul e proposta para a certificação da interrupção da transmissão da doença de chagas por Triatoma infestans. [cited 2021 May 11]. Available from: https://cevs-admin.rs.gov.br/upload/ arquivos/201611/03091534-20120427151516chagas-informede-situacao-no-estado-do-rio-grande-do-sul.pdf

18. Silva IG, Silva HH. Suscetibilidade de 11 espécies de Triatomíneos (Hemiptera, Reduviidae) à cepa ' $\mathrm{Y}$ ' de Trypanosoma cruzi (Kinetoplastida, Trypanosomatidae). Rev Bras Entomol. 1993;37:459-63.

19. Almeida CE, Francischetti CN, Pacheco RS, Costa J. Triatoma rubrovaria (Blanchard, 1843) (Hemiptera-ReduviidaeTriatominae) III: patterns of feeding, defecation and resistance to starvation. Mem Inst Oswaldo Cruz. 2003;98:367-71.

20. Almeida CE, Vinhaes MC, Almeida JR, Silveira AC, Costa J. Monitoring the domiciliary and peridomiciliary invasion 
process of Triatoma rubrovaria in the State of Rio Grande do Sul, Brazil. Mem Instituto Oswaldo Cruz. 2000;95:761-8.

21. Santos CV, Bedin C, Wilhelms, TS, Villela MM. Assessment of the Housing Improvement Program for Chagas Disease Control in the Northwestern municipalities of Rio Grande do Sul, Brazil. Rev Soc Bras Med Trop. 2016;49:572-8.

22. Priotto MC, Santos CV, Mello F, Ferraz ML, Villela MM. Aspectos da vigilância entomológica da doença de Chagas no sul do Rio Grande do Sul, Brasil. Rev Patol Trop. 2014;43:228-38.

23. Villela MM, Souza JM, Melo VP, Dias JC. Vigilância epidemiológica da doença de Chagas em programa descentralizado: avaliação de conhecimentos e práticas de agentes municipais em região endêmica de Minas Gerais, Brasil. Cad Saude Publica. 2007;23:2428-38.

24. Villela MM, Pimenta DN, Lamounier PA, Dias JC. Avaliação de conhecimentos e práticas que adultos e crianças têm acerca da doença de Chagas e seus vetores em região endêmica de Minas Gerais, Brasil. Cad Saude Publica. 2009;25:1701-10.

25. Bianchi TF, Jeske S, Sartori A, Grala AP, Villela MM. Validation of a documentar on Chagas disease by a population living in an endemic area. Braz J Biol. 2021;81:665-73.

26. Dutra AS, Stauffert D, Bianchi TF, Ribeiro DR, Villela MM. Seroprevalence of Chagas disease in Southern Brazilian cardiac patients and their knowledge about the parasitosis and vectors. Braz J Biol. 2021;81:867-71.

27. Rosenthal LD, Vieira JN, Villela MM, Jeske S, Bianchi TF. Conhecimentos sobre a doença de Chagas e seus vetores em habitantes de área endêmica do Rio Grande do Sul, Brasil. Cad Saude Coletiva. 2020;28:345-52.

28. Ribeiro AR, Mendonça VJ, Alves RT, Martinez I, Araújo RF, Mello F, et al. Trypanosoma cruzi strains from triatomine collected in Bahia and Rio Grande do Sul, Brazil. Rev Saude Publica. 2014;48:295-302.

29. Martins LP, Castanho RE, Casanova C, Caravelas DT, Frias GT, Ruas-Neto AL, et al. Rupestrian triatomines infected by Trypanosomatidae, collected in Quaraí, Rio Grande do Sul, 2003. Rev Soc Bras Med Trop. 2006;39:198-202.
30. Almeida PS, Ceretti Júnior W, Obara MT, Santos HR, Barata JM, Faccenda O. Levantamento da fauna de Triatominae (Hemiptera: Reduviidae) em ambiente domiciliar e infecção natural por Trypanosomatidae no Estado de Mato Grosso do Sul. Rev Soc Bras Med Trop. 2008;41:374-80.

31. Hamano S, Horio M, Miura S, Higo H, Iihoshi N, Noda K, Takeuchi T. Detection of kinetoplast DNA of Trypanosoma cruzi from dried feces of triatomine bugs by PCR. Parasitol Int. 2001;50:135-8.

32. Marcet PL, Duffy T, Cardinal MV, Burgos JM, Lauricella MA, Levin MJ, et al. PCR-based screening and lineage identification of Trypanosoma cruzi directly from faecal samples of triatomine bugs from northwestern Argentina. Parasitology. 2006;132:57-65.

33. Almeida CE, Duarte R, Nascimento RG, Pacheco RS, Costa J. Triatoma rubrovaria (Blanchard, 1843)(Hemiptera, Reduviidae, Triatominae) II: trophic resources and ecological observations of five populations collected in the State of Rio Grande do Sul, Brazil. Mem Inst Oswaldo Cruz. 2002:97:112731.

34. Almeida CE, Folly-Ramos E, Agapito-Souza R, Magno-Esperança G, Pacheco RS, Costa J. Triatoma rubrovaria (Blanchard, 1843) (Hemiptera-Reduviidae-Triatominae) IV: bionomic aspects on the vector capacity of nymphs. Mem Inst Oswaldo Cruz. 2005;100:231-5.

35. Salvatella R, Rosa R, Basmadjian Y, Puime A, Calegari L, Guerrero J, et al. Ecology of Triatoma rubrovaria (Hemiptera, Triatominae) in wild and peridomestic environments of Uruguay. Mem Inst Oswaldo Cruz. 1995;90:325-8.

36. Silveira AC, Rezende DF. Epidemiologia e controle da transmissão vetorial da doença de Chagas no Brasil. Rev Soc Bras Med Trop. 1994;27 Suppl 3:11-22. 